\title{
Organizational Culture in Integration of Internal and Adaptation of External (Case Study Water Management of Kahayan River in Central Kalimantan Palangka Raya)
}

\author{
R.Sally Marisa Sihombing \\ Universitas Padjadjaran \\ Bandung, Indonesia \\ risa3.emrp@gmail.com \\ Budiman Rusli \\ Universitas Padjadjaran \\ Bandung, Indonesia
}

\author{
Sintaningrum \\ Universitas Padjadjaran \\ Bandung, Indonesia \\ A.Djadja Saefullah \\ Universitas Padjadjaran \\ Bandung, Indonesia
}

\begin{abstract}
In public organizations, an understanding of the culture of the organization will help the depiction of the results of the reform of government bureaucracy in terms of conformity with the organization's culture and objectives of the reform strategy. The concept of organizational culture express the sense accepted system together, so that every organization there is a pattern of organization regarding beliefs, rituals, myths and practices that have developed since several others. Therefore, the objective of this study was to look at the cultural understanding of public organizations in the implementation of the organization's program as an internal integration and external adaptation. Through local wisdom, local communities have their own solution in dealing with problems and needs in terms of water management, and this is certainly a contribution to public organizations in a collaborative management of the river.
\end{abstract}

Keywords - public organizations, public organizations Culture, Cultural Local Communities, Culture Dayak Ngaju.

\section{INTRODUCTION}

Central Kalimantan is a region that is almost entirely covered by water, especially rivers. This condition is called the river swamp peat as Central Kalimantan region step by step peat water. More over this area is also called the ex-PLG region namely mainland estuary and dominated peatlands.

Water as a natural resource can be in the form of supplies and were also simultaneously stream. For Procurement manage river water is the responsibility of the relevant public organizations, namely Central River Region (BWS) II Kalimantan in developing policies and management of water resources of the river.

Associated with existing environmental in nature peat bog demand professionalism of the organization in managing and using water resources of the river peat. Central Kalimantan is the locus of this study conducted a special area of several regions in Indonesia because it has a function as the lungs pulmonary world. For this reason the management of peatlands, mainly river peat determine a lot of things related to public welfare and interests of Central Kalimantan national and international sustainable development. The concept of organizational culture itself can be understood from the terminology of organizational culture in the form; Dominant Culture is the prevailing culture within the organization as a whole, and a macro view of the culture that counts the color of different personalities in a culture organitation dominant (dominant culture) also shows differences or traits among organizations that one organization.

Subculture is a culture that is in units that are part of the overall subculture organitation tends to develop in large organizations that reflect collective issue, situation or experience facing members. This subculture is a mini culture in the organization, which is typically defined by the appointment of department or separation geografis. Core Values is the womb of 
the dominant culture that contains the value of the received primary or dominant throughout the organization. Shows the core values of an organization as; sensitivity on the needs of workers or community; Stakeholder has employees who are capable of generating new ideas; grip to accept the risk; Value of placed on people; Disclosure of the available communication options; Friendship and employee harmony with one another [1].

\section{RESEARCH METHOD}

Research using qualitative data analysis is a process that involves the classification of objects, people, and events and other properties that characterize all three [2]. Researchers seek to identify and to describe patterns and themes, and the viewpoint of the informant, and then trying to understand and explain patterns and themes. as long as the data are analyzed, the data are arranged categorically and chronologically, then checked back and over and sorted continuously, so that the main idea note barrage appearance.

Research the culture of public sector organizations should be undertaken as part of the accountability of accountability of the institution to the community, study of organizational culture is a cultural analysis to assess the culture now prevailing, the comparison of cultures present on the culture that you want, and evaluate the abyss separators which exist to identify cultural elements used.

\section{RESULT FINDINGS AND DISCUSSION}

To complement the meaning of the functioning of the culture of the organization, states the functions of organizational culture is; the boundary difining have roles that create differences between one organization and another, convey a sense of identity for organization members, cultural facilitate the rise of commitment to something greater than the individual self-interest, increase the stability of the social system [3]. Here culture serves as social glue that helps organizations gather together to provide a suitable standard for what is done and said employed, culture serves as a sense making and control mechanisms that guide and shape the attitudes and behaviors of employes.
In organizational culture, organizational culture has a typology which was a type of organizational culture. With the typology of organizational culture, the organization's culture professed by public and private organizations may be different, because each - each organization has different habits and apply [4]. So need an approach that is more responsive, so that it can be implemented by the perpetrators of the organization within the organization As discussed organizational culture, it can be attributed to the organizational culture introduced by describing and explaining how an organization can be developed and maintained in accordance with the organizational culture that is implemented during the organization running [5].

This relates to the circumstances of the characteristics of the organization, so how organizations can be understood and how to the relationship between members of the organization with its own organization (organizational culture) that have an impact on organizational performance. Of course, cultural values are summarized in the typology of organizational culture that offered a solution for public organizations that BWS Kalimantan II in running public service activities around the river basin.

Emphasize the importance of anthropology the realm of public policy [6]. The goal is to assist the stakeholders in the formulation of issues - issues related to the community and find solutions of concerned with the wishes and needs - the needs of local residents or communities which in turn creates a synergy between the practice and theory. The purpose of anthropology which refers to public policy is a bridge for the two gap: theory and practice.

Especially in some of the things that need to be discussed and analyzed: the national policy level and the process of globalization as well as the level of the local culture, social policy welfare, including labor and welfare family Defense Strategy, impact to adjustment and economic restructuring in the process of migration and labor unity, related to global agriculture policy, social injustice, the role of knowledge and manipulation of the company multinational, that affect the sustainability of agriculture policy, Peran anthropology in examining the impact of political and economic hegemony in a certain environment. 
Meanwhile, other anthropologists claim that the study of anthropology referring to public policies have long discussed how the relationship with public policy. Public policy in implementing the policy community becomes a relationship between a manager to run. This has an impact on how institutions and the power it has, how the institutions to delegate the meaning of ideology, rhetoric, and democracy and the politics of the local culture. So it's also talking about ethnic society, identity and interaction between global with the local.

In line with the opinion of Wedel, et.al explain the anthropology of public policy is a study that cling to policies and processes and analyzes in critiquing process. On the other hand Nader added (1974) that when talking anthropology from a public policy so here we are talking about an institution that has the full authority, and anthropology as a study of globalization that are interconnected with each other are the goals and focus in the globalization process that is how do global processes affect local communities.

The problem is that the resulting policy tend not to take the culture and the circumstances in which people lived, and interaction live in a culture that is adapted to the local environment. Likewise with a matching statement by Wedel stated anthropology of public policies is something wider and more shallow simultaneously. Broad question is a obtained along the aim to explore how the State (more precisely the institution of public policy making and have professionalism in authority to act on behalf of the state) have a relationship with local communities (population of the local community) and becomes more shallow to expand a "ethnographic focus tends". Here the public policy focus with the goal of ethnographic for a particular purpose of understanding how state policies and processes of government in an experience translated in the local community, so maintenance of a thought locally that anthropology is a recast a local or a local community that captures the reality of a changing fox.

Dayak became a term for the people living in Borneo. Dayak can refer to humans, and also means inland. But the right is the Dayak people who live in headwater. Dayak tribe has about 450 subtribes scattered throughout the province (although there are many versions of the group, ethnic cultural). However, although there are some differences between the tribe - the tribe, Dayak has a lot in common, so it is possible to assess the Dayak culture as a whole. Some authors state natives of the island of Kalimantan (Borneo) is the Dayak and Punan.

Concludes the authors' opinion earlier that the Dayak based culture, language, and geography consists of three major groups namely: North group, including the Dusun and Murut, Group from south, including Ngaju, Central group, including the Kenyah, Kayan, and Kayang and Iban. And tribal groups are now experiencing growth in view of the spread of the sellcommunity that inhabits the region a specific region. Ngaju Dayak community has a sense of the river upstream, traveling and abides the downstream. And they experience culture change for their migrants. Ngaju Dayak tribe itself is a descendant of the tribe Dayak Ot Danum is living upstream Kahayan and headwaters in West Kalimantan. Due to the openness of the Dayak Ngaju be immigrants make Dayak Ngaju different to the Dayak Ot Danum who choose to live exclusively in Ot Danum village, rather than village communities Dayak Ngaju who prefer living downriver.

For the people of Oloh (Ngaju) themselves, they identify themselves by name - the name of the river that passes through the area or areas of their bleak Oloh Kahayan, Oloh Kapuas Katingan Oloh, Oloh Barito. And the term began to be used when the Oloh Ngaju Ngaju Dayak community distinguish their tribes with Oloh tumbles (living dimuara river) and the Ot Danum Dayak community who are dihulu. For Dayak Ngaju, they call people who embraced Islam was Oloh Bakumpai, ie they are already tame Melayu (becoming Malay) or tame greeting (enter Islam) and since that time they did not identify themselves as Dayak Ngaju.

As already revealed in early researchers writing that when the Dayak people adapt themselves to the natural life. Society tends to be more use of materials, natural materials with easy to find area waters. Lanting also called rods. How do Dayak people can stay on the river by using at several rods are arranged into a place where people do domestic activities such as washing, bathing and urination. The pattern of behavior of the river of life is obliged to have a boat or boats to transport the water used to discover water, so the benefits Lanting or rod used as a community to tether the boat or boats.

Overview on the home or Huma Lanting as home residential community that supported the river 
is home to many poles anchored in aqueous or swamp land. High mast homes ranging from 3 meters with dimensions of about $5 \times 5 \mathrm{~m}$ house. In front of the house there is sanding the mast is plugged into the watery land. The door of the house there are stairs that relies on a kind of timber land pier. It can be concluded home (huma) Lanting have characteristics as follows: floating in water, inhabite by one family, home about 8-10 $\mathrm{m}$, and 6-8 $\mathrm{m}$ width of the house.

From the observations of researchers, home Lanting or trunk were encountered over the edge Kahayan, Pahandut village. Of some houses, there is a mix of cultures that is between Dayak Ngaju with Dayak culture Banjar. Ngaju Dayak culture has the hallmark in home construction is the hallmark Lanting direction toward home. Kahayan culture settled towards the river is motivated to local belief that the Dayak Ngaju oriented to the river. But now into 2000, the riverbank area Kahayan into a residential area that is not only original but Dayak community Banjar which is the community of migrants.

Characteristic of the construction of homes Lanting Banjar Dayak is not pointing to the river but the river behind. Interest migrant communities to build houses on the edge Kahayan is arguing that closer at the riverbecause the pier is the center of the development environment surrounded by houses. Overview riverside living cultural changes dominated the District Pahandut mixing two cultures of Ngaju Dayak and Banjar. This resulted in a culture of Dayak Dayak Ngaju community authority, gradually blend in with the other cultures such as the culture of Banjar. Banjar culture itself is a blend of Manyan Dayak, Dayak Ngaju and hills that are influenced by elements of Malay Javanese are then joined together by the Islamic religion, Shiva and Buddha from Banjar kingdom.

Local resident Dayak communities have land and water local managemen wisdom called Handil or Saka. It is the local knowledge possessed by Dayak communities to manage land and water. Soil and water management is done by the local communities (Dayak) called with SAKA performed by tribes of South Kalimantan. While Handil a river designation made by the people of Central Kalimantan. SAKA or Handil also a small river with a width of 2 meters, made by communities or individuals for the benefit of road transport or the flow of river water to the shape of the river with a size fit for boats, catamarans or Klotok. Handil called vary between 1 Handil with Handil others. Handil managed by one large family or one of the village, which is named in accordance with an agreement made by or under the head Handil per group. Because Handil controlled by Handil head, so everyone who took the water with the aim of irrigation plantation society, then it must be the knowledge of the head Handil. Handil is led by the head of the elder person's grandson at the group particular society or the next generation of owners Handil.

Handil made by the Dayak community is traditionally a system equipped with a water gate that proved successful rescue vast rubber plantations owned by local people. Handil a water and land management that was adopted by the porch of the basin. System block or canals or ditches built by the Dayak Ngaju used to organize and store water in fron of peat usually dry during the dry season. The water in the ditch (canal) is used to irrigate the land area or small shaped pond as pond fish trap. Swimming fish trap also called beje, from the flow of river water to irrigate large and small river (canal or ditch). Dayak community land as a pond digging fish trap is in the in front of a fish, which can be treated by the local community.

Major rivers in Central Kalimantan has an abundant amount of fish that supply though - will have no end. However, the frequent occurrence of natural phenomena, especially the region of swampy peat river, poor water management and quality conditions are bad rivers is a problem that is happening area of exPLG today. Initially for fishing activity is not the main activity but because it depends on the nature of water Dayak community to make this event into one of the main. Therefore Dayak community has long had a tradition of fishing traditionally called Indigenous Manuba of poison fish.

The abundance of fish in the a river of Borneo middle one of which is Kahayan, according Dayak tribal customs of the past, if you want to get a large amount by way MANUBA (poison) of fish in a river that many fish. Usually held in the dry season. Along with the development of more advanced age Dayak people wear some of the equipment and technology to catch fish. Equipment - equipment used by the Dayak community in the fishing done by the Dayak community is: Pisi (small fishing), pour (fishing rod to catch big fish), Tukung (utensils made from 
bamboo is installed permanently in the water), Sakang (equipment to capture the crocodile), fish trap (fishing tubular), Duhuk (Spear double-edged), Dahiling or Tangguk (for fishing), Mihing.

Mihing is a kind of tool which use to catch fish. Utensils very widely used by the Dayak community in general and the gear is admired by the Dayak community, and has been since the last three centuries ago and is widely used by residents living around the Middle Kahayan and Kahayan upstream.

Of the few things that is trusted by the Dayak community as wisdom territory, in essence, each region has its own form of local wisdom in managing the basin. A successful local action in a region could became action contradiction other parts. But if local wisdom upheld in a region of high and coupled with the culture of the people and culture that exist in each institution is in itself a powerful synergy that will be created.

Analysis researchers are problems that occur in the river basin water management Kahayan is too stressed weakness of local management action and deny the power of local knowledge possessed local communities. Yet the researchers argued that when the government recognition potensial views and local action then local knowledge will allow the birth of a more responsive policy. Not only that, decisions to be conform with state or local potential, and certainly bore water management more sustainable and effective.

\section{CONCLUSION}

To reiterate the significance of organizational culture which is translated as an accumulation brought by members - members of the organization through local culture into the organization. Thats, the organizational culture awakened from a set definition accepted by the members together, in accordance with the duties and functions of the organization so that the organization gave birth to a culture that is believed to be the hallmark of local organizations.

From this article it is an important lesson to be learned is how the culture of public organizations that perform services - especially public service watershed management, the public organization must have what is called cultural accumulation that occurs internally and externally. Internally public organizational culture has a concept of what is called internal integration through values, rituals or duties and functions, the principle held by employees of public organitation.

Organizational culture is also an accumulation of external which is something which affects the culture of public organizations, also known as external adaptation. This external adaptation is how the culture of public organizations are influenced by local culture brought by employees of public organizations as the local community. And in the process the smooth working of public organizations, as good a public organization is also concerned how the culture of the surrounding community organizations to implement programs of action for the implementation of the program. And finally it was time for public organizations carry out the implementation work program that emphasizes local handling (local culture) without denying the strength of the local culture.

\section{REFERENCES}

[1] Kreitner, Robert. \& Angelo Kinicki, 2004. Organizational Behavior, New York: MC Graw

[2] Cresswell, John.W.2010. Research Design: Qualitative, Quantitative and Mixed methods approaches, London: Sage publication.

[3] Hill.Robbins, Stephen.P. 1996 TeoriOrganisasi, Structure, DesaindanAplikasi.Terjemahan Dr. HadyanaPujaatmaka. Jakarta: Prenhallindo

[4] Robbins, Stephen.P. 1994 TeoriOrganisasi, Structure, Desain dan Aplikasi. Terjemahan Jusuf Udaya, Lic.Ec. Jakarta: Arcan

[5] Robbins, Stephen.P. \& Timothy A.Judge 2008, PerilakuOrganisasiTerjemahan Diana Angelica, et.al. Jakarta: Salemba Empat.

[6] Peacock,J. 1997, The Future Of Anthropology.Am. Anthropol.99 (1): 9-17. 